\title{
DISPARITIES IN THE SECTOR OF INFORMATION AND COMMUNICATION TECHNOLOGIES IN THE NUTS3 REGIONS IN THE CZECH REPUBLIC
}

\author{
[Rozdíly v sektoru informačních a komunikačních technologií v regionech \\ NUTS 3 v České republice]
}

\author{
Kamila Turečková ${ }^{1}$, Jan Nevima $^{2}$ \\ ${ }^{1}$ Silesian University, School of Business Administration, Univerzitni nám.1934/3, 73340 Karvina \\ Email:tureckova@opf.slu.cz \\ ${ }^{2}$ Silesian University, School of Business Administration, Univerzitní nám.1934/3, 73340 Karvina \\ Email:nevima@opf.slu.cz.
}

\begin{abstract}
The present article is focused on the analysis of selected indicators that characterize the economic sector of information and communication technology at regional levels in the Czech Republic between years 1995 and 2015. The aim of this paper is to evaluate, by a specific index that is based on a combination of point method and economical-geographic methods, regional divergences in the area of the economic branch of information and communication technology and defines development and regional differences in the ICT branch at NUTS3 level of the regions of the Czech Republic. The quest is to find regions where information and communication technology is developing and to define an order (ranking) of regions that succeeded in developing the ICT sector. The analysis of the information and communication sector which is defined by NACE Rev.2., in section J, is based on empirical data from the Czech Statistical Office at NUTS3 regional level.
\end{abstract}

Keywords: the Czech Republic, information and communication technology, region, sectoral disparities.

JEL classification: J20, L86, O14, R12

Doručeno redakci: 24.4.2018; Recenzováno: 7.5.2018; 25.5.2018; Schváleno k publikování: 13.6.2018

\section{Introduction}

Information and communication technologies play a key role in the context of current societal and economic change. In the 1990s, free and open public information began to spread through the use of the Internet and the first search engines. Soon, it was possible to produce, access and share own and private data. All these steps have led to the support of cooperation between different groups of actors, to the digitization of processes and to the network integration of companies. Through information and communication technologies, incorporating of foreign processes into own business activities has been continually stepped up in order to simplify, streamline and, in particular, reduce and cost-effectively reduce the important, especially corporate, processes and activities (Friedman 2006). The ICT sector continues to increase its share in the life of individuals, the functioning of businesses and public administration, and also plays an important role in product or service creation. Last but not least, it is an important factor affecting local, national and global economic performance (Basl 2010).

The aim of the contribution, which is the determination of the position of the Information and Communication Technologies sector in regions of the Czech Republic between 1995 and 2015, is also subordinated to its content. The content of the paper is to identify and quantify the regional differences in the NUTS 3 regions in the Czech Republic in relation to the ICT sector, which will be defined by a set of selected relevant sectoral indicators against the background of the combination of methods from the field of economic geography and measurement of 
regional disparities. Part of the contribution will be focused on an interregional comparison. On this basis, the regions will be ranked according to their involvement in the ICT sector for the year 2015. At the same time, regions will be identified at the level of the regions of the Czech Republic where this sector is concentrated from the long-term perspective. These conclusions will complement the identification of regional disparities between the regions of the Czech Republic in their involvement in the ICT sector.

The present contribution is structured as follows: Introduction, Chapter One, Literature retrieval on the topic of regional differentiations and benefits of the ICT sector for regional development and the national economy. Chapter 2, Methods and Data, describes the definition of the subject of the subsequent analysis, including the specific methods used to determine the position of the Information and Communication Technologies sector in the regions of the Czech Republic between 1995 and 2015. The IIIS $S_{i j}$ Index is then characterized. The analyses in this part are based on the calculations of the index. Characteristics of the development of the ICT sector in the Czech regions and its interregional comparison, including the determination of the sectoral disparity, is contained in the next chapter, in which mainly the results of the ICT sector analysis performed in the regions of the Czech Republic are presented. Finally, the Conclusion summarizes the most important conclusions resulting from the analyses. The partial values of the calculated $I I I S_{i j}$ Index are given in the Appendix.

\section{Literature review}

The issue of monitoring regional disparities is a research phenomenon of the last decades when a great polarization of elements, processes, and activities and differences between individual regions has been experienced (Jeníček et al. 2010). The very definition of regional disparities differs across the theories of regional development (Hučka 2007). Regional disparities can be found in the social, economic and territorial spheres. According to Jeníček et al. (2010), causes of uneven development and sources of regional disparities can be found in three sets of factors: (1) natural conditions - the amount of mineral wealth, geographic location in terms of distance to centres of trade and significant logistical hubs, differences in climatic conditions, (2) sociocultural factors - values and traditions that determine access to innovation, entrepreneurship, mobility, psychological factors, etc., (3) political and economic factors - deliberate or even unconscious support for the needs of the urban population and the development of selected urban areas, etc. Kutscherauer et al. (2008), on the other hand, understand the regional disparity as the difference that results from the natural development of a real-world economy.

In the context of the contribution, the regional differences will be defined according to the Organization for Economic Co-operation and Development (OECD 2002, 2003) where the economic phenomenon is the ICT sector in the Czech Republic and when the regional disparities express the degree of difference in the intensity of the examined economic phenomenon regions of that country. Regional disparity indicates the degree to which the intensity of an economic phenomenon varies across regions within a given country. The regional sectoral disparity will then represent the notional distance quantified by the difference between the selected sectoral index (index) between the region with the best value in the selected sectoral index (index) and the sector index (index) determined for the region under review. In other words, the regional sectoral disparity will be understood as the difference between a set of values based on the quantification of a set of sectoral characters transformed into an index in a given region and a region with the best value. From the point of view of the contribution, regional differences will be perceived as positive and therefore desirable. Exploring the diversity of subjects and their relevant features leads to the recognition of their uniqueness, their ability to effectively and effectively distinguish themselves from other 
subjects, and thus to use their comparative advantage in their own and in society (Kutscherauer et al. 2010). According to Geppert and Stephan (2008), strengths (positive regional disparities) usually result in the comparative, competitive advantages of the object under consideration, which usually consist of unique and valuable resources and unique capabilities to use these resources. The role of positive disparities can be found to be a driver of development and a source of comparative advantages and therefore a source of competitiveness (Rodrigeuz-Pose and Ezcurra 2009).

Information and communication technologies are ubiquitous. They have changed products and services, forms of communication and the activities of a number of institutions. According to Roche (2016), information and communication technologies have been a driving force of the production of goods and services since the beginning of the computer age (around 1936). ICT has increased the production potential of individual entities and economies. They have enabled national firms to be transformed into multinational enterprises, deepened globalization processes, contributed to the sharing of innovation and improved scientific cooperation across the world. Information and communication technologies support the geographical concentration of other industries, which subsequently benefit from the existence of network externalities and show faster growth. ICT thus indirectly supports the development of other sectors through the desired interconnection of interested enterprises (Hong and $\mathrm{Fu} 2011$ ). Current studies attribute information and communication technology to the importance of generating itself and international transfer of innovation, which contributes to the growth of industry and industrial production, both at macroeconomic and microeconomic level. Especially for individual companies and entire economies located on the technological frontier, the transfer and use (through ICT) of new innovations and information and communication technologies enable the potential for further growth and development (Razvadovskaya et al. 2015). The innovation potential of ICT has not yet been exhausted. New technologies, newly designed applications, ICT services, and the whole business models emerging from ICT have emerged. The continuing high innovation dynamics in the ICT sector itself and its impact on the functioning of other industries make a significant contribution to overall productivity growth (Basl 2010).

The Information and Communication Technologies sector has significant potential for the future development of economies and societies through the high added value it generates and is one of the most stable sources of particularly qualitative economic growth today and in the future (Voříšek, Novotný et al. 2010; Dedrick, Gurbaxani and Kraemer 2003; Kitson, Martin and Tyler 2004). Also, the influence of information and communication technologies transformed into material capital goods has proven to be of great importance for its contribution to economic growth (Schreyer 2000). The ICT sector is also important for its contribution to the competitiveness of the economy at both microeconomic and corporate level (Dedrick, Gurbaxani and Kraemer 2003; Kramer, Jenkins and Katz 2007) and macroeconomic (Venturini 2008; Dedrick, Kraemer and Shih 2013 or Jorgenson 2001). This conclusion is confirmed by Doucek and Nedomo (2011) who consider ICT and their applications as a relevant factor for the competitiveness of countries where the development of this sector is directly and indirectly transformed into the development of other economic sectors. Atkinson and Castro (2008) consider economic activities linked to the ICT sector as the main innovation driving force of individual economies and investing in the ICT sector as an important resource for creating new jobs, particularly in the area of services. According to the European Commission (2010), the ICT sector makes a significant contribution to GDP, while it is confirmed that over the last twenty years ICT sector growth has increased by $10 \%$ to $0.6 \% \%$ (OECD 2012). In connection with this finding, Voř́šsek, Novotný et al. (2010) mentioned that the multiplier effects of ICTs 
have contributed to the enhancement of the performance and quality of public administration and productivity gains in other sectors, with $50 \%$ growth in productivity in the EU work just the application created by the ICT sector. According to EU documents, the ICT sector directly contributes 5\% to European GDP and its market value amounts to 660 billion EUR per year (Europe 2020, 2010).

In the Czech Republic, some of the strongest economic activities and activities (Vorríšek, Novotný et al. 2010) are the economic activities included in the ICT sector, together with the sector related to the creation, adjustment, and trading of energy and financial and insurance services. At the same time, on the basis of a comparison of the developments and the level of gross added value created by the ICT sector in the European Union, it was confirmed that the performance in this sector is comparable in the Czech Republic to other EU countries or even stronger. According to the Czech ICT Alliance (2014), one of the ways to increase our country's competitiveness includes supporting ICT services, developing their applications, and generating support for science and research with reference to the development of ICT products. For this reason, it is necessary to create and deepen the conditions for the development of this sector, both at local and regional and national levels. In recent years, the ICT sector has been seen as one of the key areas of economic activity that has significant potential for further development and which, thanks to the high added value it generates, is one of the most important sources of stable economic growth in today's and future economies. The ICT sector is characterized by multiplier effects in the economy, where activities in this sector directly or indirectly affect outputs in other sectors, contribute to significant savings and productivity growth, increased intellectual capital, and the growth of social value generated by the synergy of knowledge, information, and technology, which are being developed, developed and supported by this sector of the economy. All these positive effects associated with business activities in the ICT sector increase the competitiveness of the regions in which they operate and contribute to improving the quality of life and living standards (Turečková 2014).

Dynamic developments in the Information and Communication Technologies sector are currently substantially contributing to the positive economic performance of a number of companies and are also characterized by an important impact on the economy as a whole and have the high potential not only to be utilized but above all to further develop.

\section{Methods and data}

The Information and Communication Technologies (ICT) sector is defined on the basis of the standard classification of economic activities used in the European NACE Rev. 2 area. 2. section J in the regions of the Czech Republic (NUTS 3 regional level) in 1995-2015 through secondary data, the source of which is the Czech Statistical Office (Database of Regional Accounts). The input indicators for determining the regional status of the ICT sector in the sectoral breakdown are: gross value added at current prices, employees (employees), the compensation of employees and gross fixed capital formation, all for the period analyzed 21 years at the regional level as well as the Czech Republic as a whole.

Determining the level of the Information and Communication Technologies sector at regional level relies on a mutual combination of two approaches to measuring the size of the sector in the lower territorial unit. It is a point method and set of methods based on economic geography. Using the point method, we assign index pointers to individual industry indicators according to their level and their subsequent aggregation creates an integrated index $\left(_{i j}\right)$ that quantifies the level of the sector in the region in the context of selected sub-indices. For more on the point method, see Tuleja (2010) or Turečková (2015a). The core of economic and geographic methods is to find out the relevant degree of concentration and localization of the sector under 
consideration in the region to the level of the higher territorial unit. The chosen economicgeographic methods for measuring concentration and specialization of the ICT sector, reflecting the level of ICT responses, were selected: Herfindahl indexes for concentration and specialization, and the general Index of Specialization, which is based on partial calculations of Herfindahl indexes and is generated by their mutual product. The Specialization Coefficient $\left(I S_{i j}\right)$ is the basic indicator characterizing the specialization of the sector under consideration in the selected territorial unit. It is the regional share of the sectoral characteristics (usually sectoral employment or sectoral value) of the overall sectoral characteristics of the whole analyzed region (e.g. the state). The coefficient or the index, the specialization informs about the orientation of the territory in terms of the sector structure of the economy. It gives an idea of the degree of significance of the sector in the given territorial unit compared to the position of the branch in the hierarchically higher spatial unit (Toušek et al. 2008). For more on Selected Economico-Geographical Methods refer to Turečková and Martinát (2016), Campos (2012), Goschin et al. (2009) or Rhoades (1993).

For the purpose of linking the point method and the methods of economic-geographic analysis, the IIIS $S_{i j}$ Index was artificially created, through which the regional disparities will be defined in the practical part. The IIIS $S_{i j}$ Index is calculated as the product of the integrated index $\left(I_{i}\right)$ obtained in the background of the point method and the index of specialization $\left(I S_{i j}\right)$, which combines the Herfindahl Concentration Index $\left(g_{i j}^{C}\right)$ and the Herfindahl Specialisation Index $\left(g_{i j}^{S}\right)$ :

$$
I S_{i j}=g_{i j}^{C} \times g_{i j}^{S} \times 100
$$

where $^{1}$

$$
g_{i j}^{C}=\frac{X_{i j}}{\sum_{i=1}^{n} X_{i j}}=\frac{X_{i j}}{X_{j}} \quad \text { and } \quad g_{i j}^{S}=\frac{X_{i j}}{\sum_{j=1}^{m} X_{i j}}=\frac{X_{i j}}{X_{i}}
$$

and $^{2}$

where

$$
I_{i}=\frac{1}{p} \sum_{i=1}^{p} B_{i j}
$$

$$
B_{i j}=\frac{x_{i j}}{x_{j \max }}
$$

The $I I I S_{i j}$ Index is given by:

$$
I I I S_{i j}=I S_{i j} \times I_{i}
$$

For the IIIS $S_{i j}$ Index, the higher the IT region is, the more successful it is. This assertion is based on the fact that the same conclusion applies both to the integrated index and to the Index of

\footnotetext{
${ }^{1}$ where: $i$ - region; $j$ - sector (economic sector); $X$ - total national gross value added; $X_{i j}$ - gross value added of sector $j$ in region $i ; X_{j}$ - gross value added of sector $j ; X_{i}$ - total gross value added in region $i ; g_{i j}^{C}$ - share of region $i$ on total gross value added done via sector $j ; g_{i j}^{S}$ - share of sector $j$ on total gross value added done via region $i$.

${ }^{2}$ where: $B_{i j}$ - the point value of $j$ indicator for $i$ region; $x_{i j}-$ value of $j$ indicator for $i$ region; $x_{j} \max -$ the maximum value of $j$ indicator.
} 
Specialization. Through the $I I I S_{i j}$ Index, each region can be assigned a value that reflects its position in ICT, and at the same time the difference between the IIIS $S_{i j}$ Index for the best region defined by the highest value of the IIIS $S_{i j}$ Index and the IIIS $S_{i j}$ Index for the weakest region (with the lowest index value) and the sector under consideration. In other words, the regional sectoral disparity will be understood as the difference between a set of values based on the quantification of a set of sectoral characters transformed into a multi-criterion index in a given region and a region with that best value. The Microsoft Excel 2010 software program was used for own calculations. All calculations for the IIIS $S_{i j}$ are shown in the Appendix.

\section{Results and Discussion}

The results of the $I I I S_{i j}$ Index have enabled the inter-regional sectoral differences to be quantified alternatively and to characterize their evolution. The ranking of regions of the Czech Republic in their involvement in the ICT sector identified by the IIIS $S_{i j}$ Index in 1995 and 2015 is shown in Figure 1. Reinforced between the analyzed years is the strengthening of the ICT sector in the Capital City of Prague (Prague), the South Moravian Region and the MoravianSilesian Region, and the decline in the other regions ${ }^{3}$. At the same time, it is confirmed that there are four, respectively, five separate groups of regions with a different intensity of involvement in ICT. Finally, from the factual deviation of individual regions, the growth of sectoral differences across Czech regions and the growth of the overall sectoral disparity is obvious. Table on Appendix shows the magnitude of the overall sectoral disparity in the Czech Republic, expressed through the IIIS $S_{i j}$ Index.

Figure 1: Regions and their ICT sectors and sectoral regional disparities determined by the IIIS $i j$ Index for 1995 and 2015

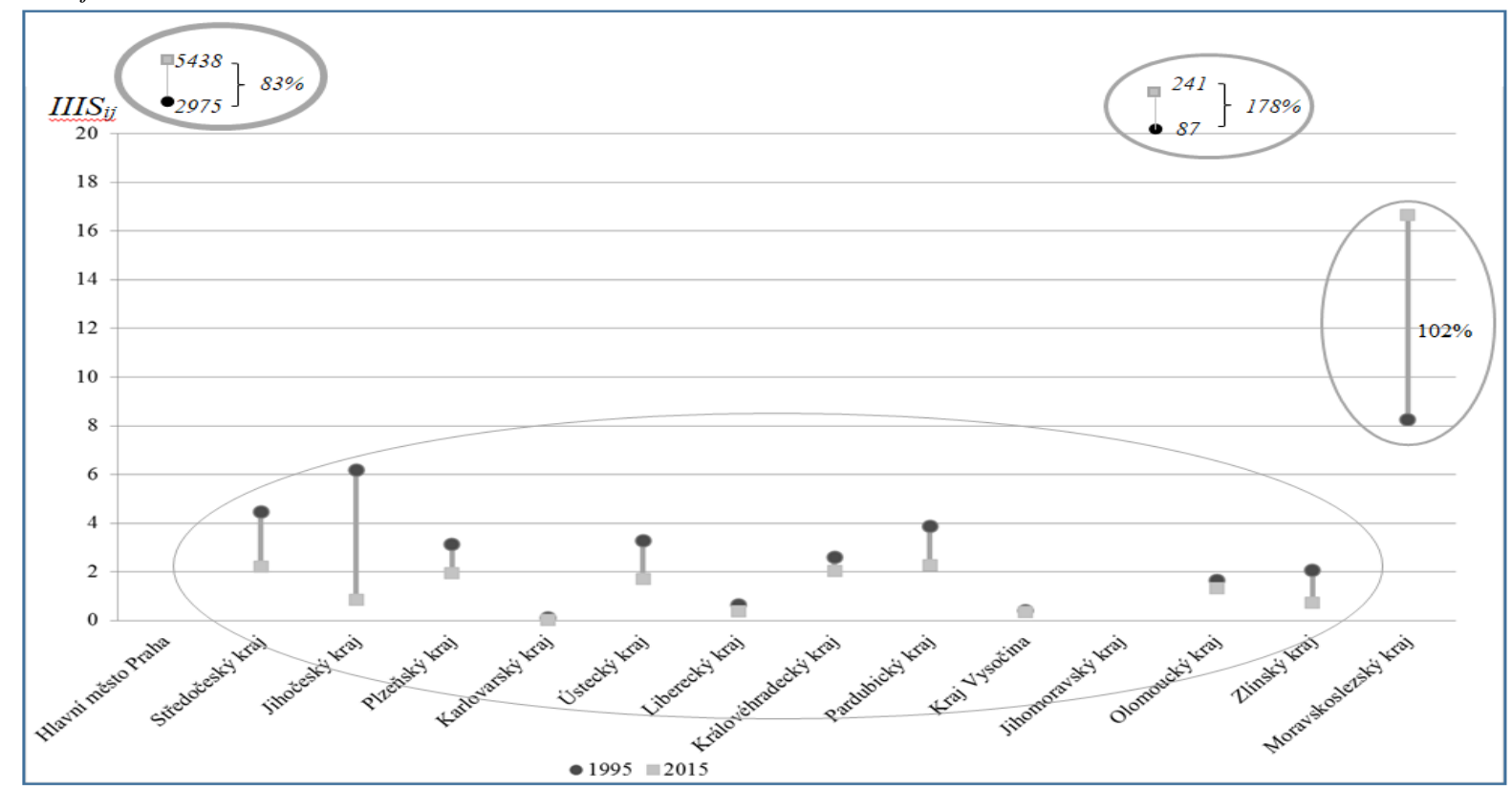

Note: The scale does not apply to the Capital City of Prague and the South Moravian Region.

Source: CZSO Regional Accounts Database

\footnotetext{
${ }^{3}$ There are 14 regional units included in NUTS3 in the Czech Republic, namely Prague (Hlavní město Praha), Central Bohemia Region (Středočeský kraj), South Bohemia Region (Jihočeský kraj), The Plzen Region (Plzeňský kraj), The Karlovy Vary Region (Karlovarský kraj), The Usti Region (Ústecký kraj), The Liberec Region (Liberecký kraj), The Pardubice Region (Pardubický kraj), The Hradec Kralove Region (Královehradecký kraj), The Vysocina Region (Kraj Vysočina), The South Moravian Region (Jihomoravský kraj), The Zlin Region (Zlínský kraj), The Olomouc Region (Olomoucký kraj) and The Moravian-Silesian Region (Moravskoslezský kraj).
} 
Figure 2 presents more clearly the results of the development of a sectoral disparity that reflects the overall development of the ICT sector in the Czech Republic. This disparity is calculated as the difference between the highest and lowest index values in a given set of regions and the year in question (see Appendix). There is a growing trend in the development of inter-regional differences. Thus, differences in the involvement of regions in ICT have increased between 1995 and 2015. The gap between regions in their involvement in the ICT sector has increased by almost $83 \%$ over the studies period of 21 years. It is clear from the graph that in 2008 and 2010 there was a short-term decline in the sectoral disparity and at the same time the growth rate of the disparity slowed down in the second half of the reporting period.

In the background of the presented result of the development of interregional differences in the ICT sector, one can see a significant fact, namely that the South Moravian Region has been separated from the group, whose disparity towards Prague has decreased significantly in recent years, while the difference between it and the other group of regions is growing. The same, but to a lesser extent is also the characteristic of the Moravian-Silesian Region.

Figure 2: Development of the sectoral disparity according to the index $I I I S_{i j}$ between 1995 and 2015

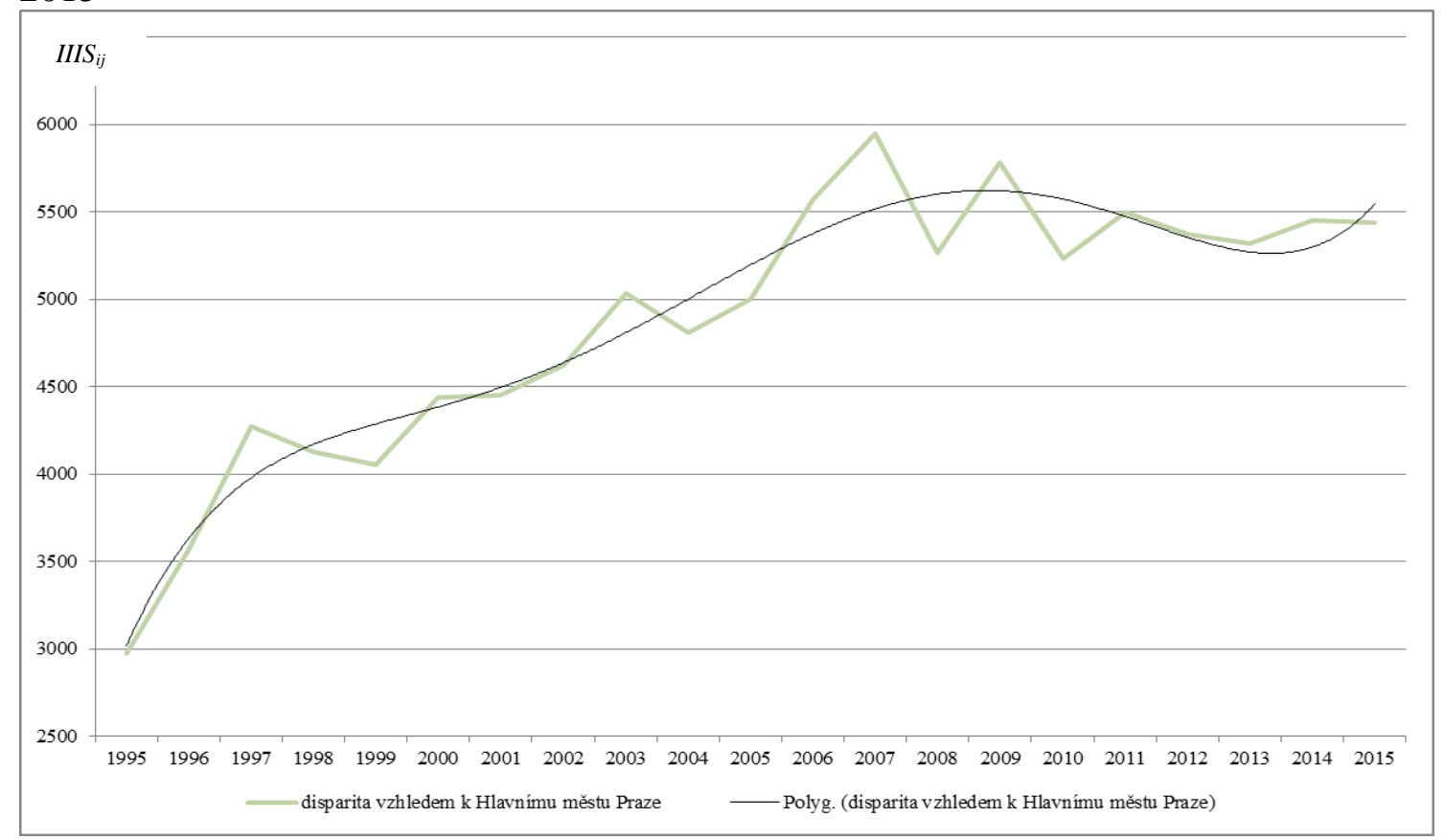

Note: Fifth Order Polynomial Function, R2=0,932.

Source: CZSO Regional Accounts Database, modified by authors

Figure 3 shows the ranking of regions according to the index $I I I S_{i j}$ in 1995 and 2015. 3 regions (The Zlin Region, South Bohemia Region and The Usti Region) have deteriorated in comparison with 1995, 4 regions have improved (The Olomouc, The Hradec Kralove, The Plzen and The Pardubice Regions) and the other 7 regions you have kept their order unchanged.

The following conclusions can be drawn from the combinations presented above: (1) The ICT sector is developing only positively in three regions of the CR (Capital City of Prague, South Moravian Region, Moravian-Silesian Region), in other regions, the concentration of the sector is more or less intense in the same triad of regions of the Czech Republic, (3) the overall sectoral disparity across the $\mathrm{CR}$ is increasing, i.e. the regions are moving away from ICT activities and the ICT sector is polarized between the regions of the Czech Republic. 
Figure 3: Ranking of regions involved in ICT activities in regions of the Czech Republic for 1995 and 2015 according to the index $I I I S_{i j}$

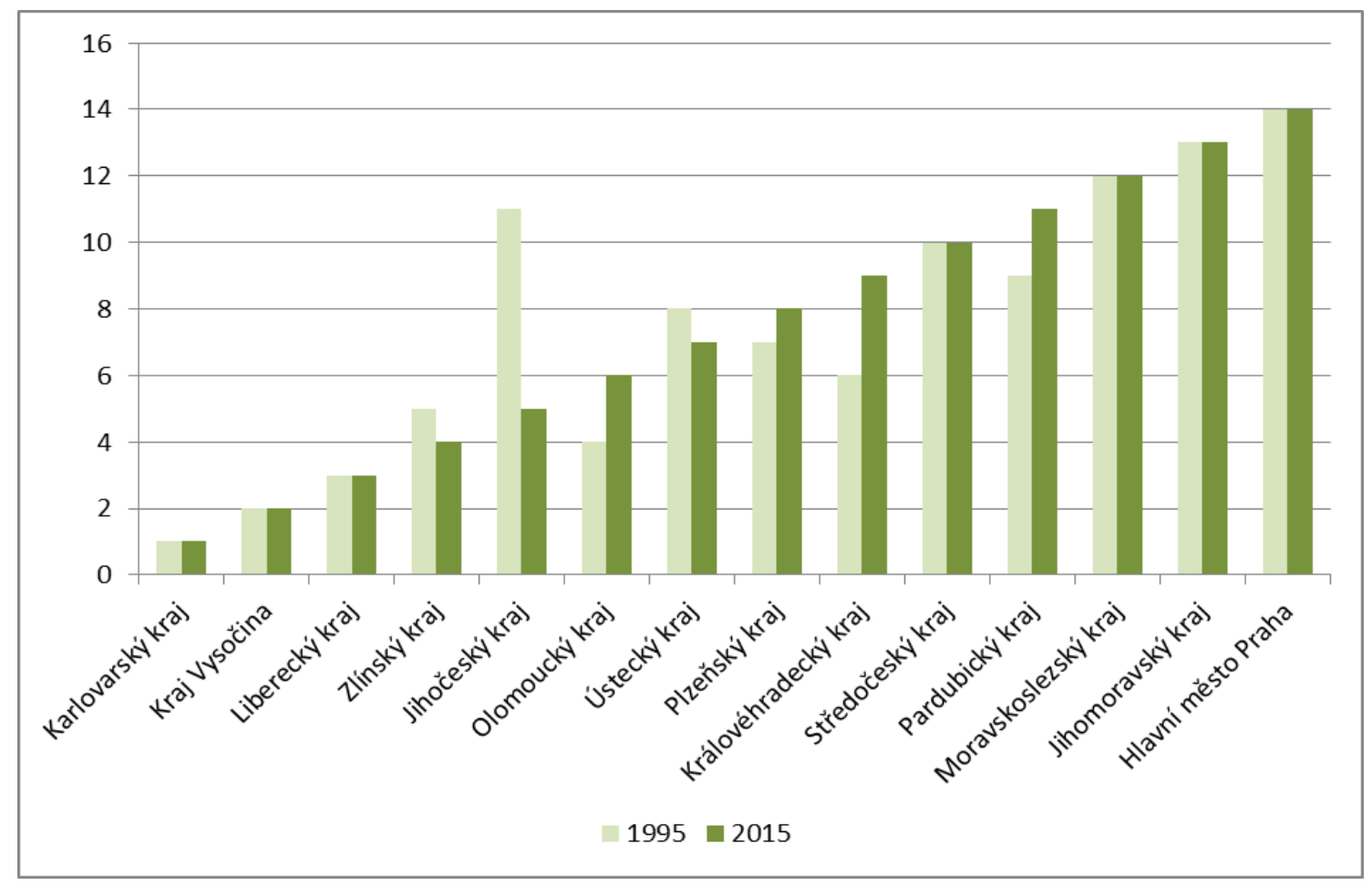

Note: Sorted by index value for the year 2015.

Source: CZSO Regional Accounts Database, modified by authors

\section{Conclusion}

The aim of the submitted paper was to determine the position and interregional development of the Information and Communication Technologies sector in the regions of the Czech Republic in the period 1995-2015 in the background of the chosen methods. The sectoral IIIS $i j$ Index, which evaluates the ICT sector at the regional level, is based on a combination of partial indices methods and methods of economic-geographic analysis. The intent of interconnecting individual methods into one aggregate index was to improve the quantified level of ICT in individual regions.

Measured by the $I I I S_{i j}$ index, the sectoral disparity in 1995 was 2975 points and 21 years later it was 5438 points. Overall, differences in the ICT sector between the Czech Republics increased, increasing the uneven distribution of ICT activities between regions in the Czech Republic. In an interregional comparison, the sectoral disparity only declined between Prague and the South Moravian Region, which suggests that this region was the only one to improve its position in the area of ICT towards the Capital City of Prague. The ranking of regions in their involvement in the ICT sector in 2015 is, therefore, the following: in the first place and the most successful region in the Czech Republic is the Capital City of Prague, followed by The South Moravian Region ( $2^{\text {nd }}$ place) and The Moravian-Silesian Region ( $3^{\text {rd }}$ place). The fourth successful region in 2015 in ICT activities was the Pardubice Region, where the regions of Central Bohemia, Plzen, Hradec Kralove and Usti were located. The $9^{\text {th }}$ and $10^{\text {th }}$ places belong to The Olomouc and South Moravian Regions. The ICT sector in the Karlovy Vary Region is the worst performing and in the last $14^{\text {th }}$ place. The Vysočina Region, the Liberec Region and the Zlin Region $\left(13^{\text {th }}, 12^{\text {th }}\right.$ and $11^{\text {th }}$ place $)$ are also unsuccessful in the ICT sector. The general widening of regional disparities in the ICT sector can be explained by concentration processes 
where firms naturally strengthen their position in regions where ICT is concentrated and vice versa. The concentration of the same sector in the sector can be explained by the existence of the positive externalities and the effects that these processes and the operations of companies in the sectoral agglomeration provide. At the same time, it is necessary to emphasize the influence of universities in the sense of the labor force in the regions where ICT activities are successful (Turečková 2018 and Turečková 2015b).

\section{Acknowledgement}

This paper was created with the support of the SGS/13/2015 project "The Impact of Selected Macroeconomic and Microeconomic Determinants on the Competitiveness of Regions and Companies in the Visegrad Group plus".

\section{References}

[1] ATKINSON, R. D. and D. D. CASTRO, 2008. Digital Quality of Life. [online]. [vid. 201406-20]. Available at: http://www.itif.org/files/DQOL.pdf.

[2] BASL, J., 2010. Př́stupy a trendy v inovacích informačních a komunikačních technologií ve společnosti a ekonomice. [online]. [2017-04-20]. Dostupné $\mathrm{z}$ Available at: https://is.muni.cz/do/econ/soubory/oddeleni/centrum/papers/19Basl.pdf.

[3] CAMPOS, C., 2012. The Geographicalal Concetration of Industries. Office for National Statistics. [online]. [2016-02-02]. Available at: http://www.ons.gov.uk /ons/ dcp171766_ 272232.pdf.

[4] Czech ICT Alliance, 2014. Czech ICT Alliance. [online]. [2014-06-21]. Available at: http://www.czechict.cz/.

[5] CzechInvest, 2014. ICT. [online]. [2014-06-22]. Available at: http://www.czech invest.org/en/ict.

[6] ČSÚ, 2016. Databáze regionálních účtů. [online]. [2015-05-16]. Available at: http://apl.czso.cz/pll/rocenka/rocenkavyber.volba?titul=Vybran\%E9\%20ukazatele\%20v $\% 20 \mathrm{odv} \% \mathrm{ECtvov} \% \mathrm{E} 9 \mathrm{~m} \% 20 \% \mathrm{E} 8 \mathrm{len} \% \mathrm{ECn} \% \mathrm{ED} \& \mathrm{mypriznak}=\mathrm{RD} \& \mathrm{typ}=1 \&$ proc=rocenk a.presB \&mylang $=\mathrm{CZ} \& \mathrm{jak}=4$.

[7] DEDRICK, J., V. GURBAXANI and K. L. KRAEMER, 2003. Information Technology and Economic Performance: A Critical Review of the Empirical Evidence, ACM Computing Surveys, 35(1), pp. 1-28.

[8] DEDRICK, J., K. L. KRAEMER, and E. SHIH, 2013. IT and Productivity in Developed and Developing Countries. [online]. [2015-03-23]. Available at: http://www.globdev.org/files/

ProceedingsThird\%20Annual\%20SIG\%20Globdev\%20Workshop/24-PAPER-DedrickKraemer-Shih-IT-and-Productivity.pdf.

[9] DOUCEK, P. a L. NEDOMOVÁ, 2011. Porovnání ICT sektorů v České republice a Slovenské republice. AOP, 19(5), pp. 68-86.

[10] European Commission, 2010. Europe's Digital Competitiveness Report 2010. [online]. [2014-06-15]. Available at: http://ec.europa.eu/information_society/newsroom/cf/item detail.cfm?item_id=6499.

[11] Europe 2020, 2010. Strategy for smart, sustainable and inclusive growth. [online]. [201704-15]. Available at: http://ec.europa.eu/eu2020/pdf/COMPLET EN BARROSO 007 Europe 2020 - EN version.pdf. 
[12] FRIEDMAN, T. L., 2006. The World is Flat - The globalized world in the Twenty-first century. 2nd edition. New York: Penguin Books.

[13] GEPPERT, K. and A. STEPHAN, 2008. Regional disparities in the European Union: Convergence and agglomeration. Papers in Regional Science, 87(2), pp. 193-217.

[14] GOSCHIN, Z., D. L. CONSTANTIN, M. ROMAN and B. V. ILEANU, 2009. Specialization and Concentration Patterns in the Romanian Economy. Journal of Applied Quantitative Methods, 4(1), pp. 95-111.

[15] HONG, J. and S. FU, 2011. Information and Communication Technologies and the Geographical Concentration of Manufacturing Industries. Urban studies, 48(11), pp. 23392354.

[16] HUČKA, M., 2007. Vznik a přičiny územních nerovností. Regionální disparity. Working Paper, 1(1), 13-19. [online]. [2015-03-08]. Dostupné z: http://disparity.vsb.cz/ pdf /pracovni_listy.pdf.

[17] JENÍČEK, V. a kol., 2010. Vyvážený rozvoj. Na globální a regionální úrovni. Praha: C. H. Beck.

[18] JORGENSON, D. W., 2001. Information Technology and the U.S. Economy. [online]. [2015-03-08]. Available at: http://scholar.harvard.edu/files/jorgenson/ files/itanduseconomy_americaneconomic review.pdf.

[19] KITSON, M., R. MARTIN, and P. TYLER, 2004. Regional Competitiveness: An Exlusive yet Key Concept? [online]. [2014-06-05]. Available at: http://michaelkitson.files.wordpress.com/ 2013/02/kitson-marrtin-tyler-rs-2004.pdf.

[20] KRAMER, W. J., B. JENKINS, and R. S. KATZ, 2007. The Role of the Information and Communications Technology Sector in Expanding Economic Opportunity. [online]. [201504-13]. Available at: http://www.hks.harvard.edu/mrcbg/CSRI/publications/report_22_EO\%20ICT\%20 Final.pdf.

[21] KUTSCHERAUER, A. a kol., 2008. Teorie, identifikace, klasifikace a hodnocení regionálních disparit. Průběžná výzkumná zpráva. [online]. [2016-04-08]. Available at: http://alkut.cz/edice_cd/cd4_rocni_zprava_2008/pdf/vyzkumna_zprava_2008.pdf.

[22] KUTSCHERAUER, A. a kol., 2010. Disparity v regionálním rozvoji české republiky pojetí, teorie, klasifikace a hodnocení. Závěrečná výzkumná zpráva[online]. [2015-04-01]. Available at: http://alkut.cz/edice_cd /cd9_prilohy_e-projekt_2010/pdf/ zaverecna_ zprava_2010.pdf.

[23] OECD, 2002. Geographic Concentration and Territorial Disparity in OECD Countries. Paris: OECD Publications Service.

[24] OECD, 2003. Geographic Concentration and Territorial Disparity in OECD Countries. Paris: OECD Publications Service.

[25] OECD, 2012. OECD Guide to Measuring the Information Society 2012. [online]. [201510-09]. Available at: https://www.itu.int/en/ITUD/Statistics/Documents/publications/mis2012/MIS2012_without_Annex_4.pdf.

[26] RAZVADOVSKAYA, Y., I. SHEVCHENKO and M. GREZINA, 2015. The role of the sectoral concentration, foreign investment and government support in the innovation strategy of the Russian enterprises of the ICT industry. Terra Economicus, 13(4), pp. 6582. 
[27] RHOADES, S. A., 1993. The Herfindahl-Hirschman Index. [online]. [2016-02-08]. Available at: https://fraser.stlouisfed.org/docs/publications/FRB/pages/ 19901994/33 101_1990-1994.pdf.

[28] ROCHE, E. M., 2016. Information and Communication Technology Still a Force for Good? Journal of global information technology management, 19(2), pp. 75-79.

[29] RODRIGUEZ-POSE, A. and R. EZCURRA, 2009. Does decentralization matter for regional disparities? A cross-country analysis. Journal of Economic Geography, 49(1).

[30] SCHREYER, P., 2000. The Contribution of Information and Communication Technology to Output Growth: A Study of the G7 Countries. OECD Science, Technology, and Industry Working Papers, 2000/02, OECD Publishing. http://dx.doi.org/10.1787/151634666253.

[31] TOUŠEK, V., J. KUNC a J. VYSTOUPIL, 2008. Ekonomická a sociální geografie. Plzeň: Vydavatelství a nakladatelství Aleš Čeněk.

[32] TULEJA, P., 2010. Praktická aplikace metod hodnocení regionálních disparit. In. Acta academica karviniensia, 1(1), pp. 496-509.

[33] TUREČKOVÁ, K. and S. MARTINÁT, 2016. Selected methods of economicalgeographic analysis of national economical sectors. Working Paper in Interdisciplinary Economics and Business Research no. 26. Silesian University in Opava, School of Business Administration in Karviná. Available at: http://www.iivopf.cz/images/Working_papers/WPIEBRS2016/WPIEBRS_26_Tureckova _Martinat.pdf.

[34] TUREČKOVÁ, K., 2014. Dekompozice faktorů konkurenceschopnosti regionů v oblasti ICT sektoru. In: Sbornik recenzovaných př́spěvki̊ z 2. ročníku mezinárodni vědecké konference Ekonomika a řizeni podniku ve 21. století. Ostrava: VŠB-TU Ostrava, pp. 187193.

[35] TUREČKOVÁ, K., 2015a. Hodnocení regionálních disparit v odvětví informačních a komunikačních technologií v České republice. In: Proceedings of the 7th International conference for doctoral students and young scientists. Karviná: SU OPF Karviná, pp. 207216.

[36] TUREČKOVÁ, K., 2015b. Industrial coalitons and education in context of information and communication technology sector in Czech Republic. In: Proceedings of 12th International Scientific Conference Economic Policy in the European Union Member Countries. Karviná: SU OPF Karviná, pp. 837-845. ISBN 978-80-7510-114-3.

[37] TUREČKOVÁ, K., 2018. Localization theory of regional development and agglomeration effects: A case study of the ICT sector in the Czech Republic. Geographia Technica, 13(1), 119-129. ISSN 2065-4421.

[38] VENTURINI, F., 2008. Information technology, research \& development, or both? What really drives a nation's productivity. [online]. [2015-02-08]. Available at: http://www.dea.univpm. it/ quaderni/pdf/321.pdf.

[39] VOŘÍŠEK, J., O. NOVOTNÝ a kol., 2010. ICT a konkurenceschopnost České republiky. [online]. [2014-09-03]. Available at: http://www.cssi.cz/cssi/studie-ictkonkurenceschopnost. 
Appendix: the $I I I S_{I J}$ index and disparity in individual regions of the Czech Republic in the period of $1995-2015$

\begin{tabular}{|c|c|c|c|c|c|c|c|c|c|c|c|}
\hline region/year & 1995 & 1996 & 1997 & 1998 & 1999 & 2000 & 2001 & 2002 & 2003 & 2004 & 2005 \\
\hline Cap.City of Prague & 2975,49 & 3568,14 & 4272,06 & 4130,10 & 4056,72 & 4437,21 & 4451,68 & 4624,72 & 5034,85 & 4810,14 & 5000,24 \\
\hline Central Bohemia Region & 4,46 & 4,93 & 5,68 & 5,87 & 5,37 & 5,26 & 6,01 & 6,47 & 7,85 & 8,23 & 2,91 \\
\hline South Bohemia Region & 6,19 & 6,81 & 4,79 & 4,76 & 4,64 & 4,35 & 4,56 & 4,92 & 4,65 & 3,75 & 4,16 \\
\hline The Plzen Region & 3,13 & 3,76 & 4,38 & 4,15 & 2,84 & 3,86 & 3,02 & 2,64 & 2,06 & 1,80 & 3,20 \\
\hline The Karlovy Vary Region & 0,11 & 0,14 & 0,10 & 0,09 & 0,08 & 0,07 & 0,07 & 0,06 & 0,06 & 0,07 & 0,08 \\
\hline The Usti Region & 3,28 & 5,08 & 3,53 & 3,46 & 2,63 & 2,81 & 2,73 & 2,47 & 2,23 & 1,38 & 3,22 \\
\hline The Liberec Region & 0,63 & 0,66 & 0,63 & 0,58 & 0,53 & 0,53 & 0,42 & 0,54 & 0,37 & 0,40 & 0,53 \\
\hline $\begin{array}{l}\text { The Hradec Kralove } \\
\text { Region }\end{array}$ & 2,60 & 3,22 & 4,60 & 3,38 & 3,32 & 3,88 & 3,24 & 3,54 & 3,30 & 3,76 & 1,96 \\
\hline The Pardubice Region & 3,88 & 3,65 & 3,49 & 3,24 & 2,93 & 3,71 & 3,23 & 3,05 & 2,45 & 2,58 & 3,83 \\
\hline The Vysocina Region & 0,42 & 0,59 & 0,65 & 0,59 & 0,43 & 0,48 & 0,66 & 0,68 & 0,40 & 0,57 & 0,53 \\
\hline $\begin{array}{l}\text { The South Moravian } \\
\text { Region }\end{array}$ & 86,72 & 85,38 & 64,70 & 64,63 & 69,36 & 59,83 & 51,99 & 54,58 & 57,83 & 51,82 & 77,42 \\
\hline The Olomouc Region & 1,65 & 1,85 & 2,21 & 2,21 & 1,76 & 1,67 & 1,71 & 2,07 & 1,58 & 1,35 & 1,96 \\
\hline The Zlin Region & 2,07 & 1,43 & 1,33 & 1,23 & 1,19 & 1,16 & 0,96 & 1,03 & 0,95 & 0,85 & 0,91 \\
\hline $\begin{array}{l}\text { The Moravian-Silesian } \\
\text { Region }\end{array}$ & 8,26 & 8,12 & 10,06 & 8,63 & 9,14 & 9,25 & 9,24 & 9,26 & 7,31 & 6,59 & 9,92 \\
\hline $\begin{array}{l}\text { Disparity against the } \\
\text { Capital City of Prague }\end{array}$ & 2975,39 & 3568,00 & 4271,96 & 4130,01 & 4056,65 & 4437,14 & 4451,61 & 4624,66 & 5034,79 & 4810,07 & 5000,16 \\
\hline $\begin{array}{l}\text { Disparity between Capital } \\
\text { City of Prague and The } \\
\text { South Moravian Region }\end{array}$ & 2888,77 & 3482,76 & 4207,36 & 4065,47 & 3987,36 & 4377,38 & 4399,69 & 4570,14 & 4977,02 & 4758,32 & 4922,82 \\
\hline region/year & 2006 & 2007 & 2008 & 2009 & 2010 & 2011 & 2012 & 2013 & 2014 & 2015 & change \\
\hline Cap.City of Prague & 5570,88 & 5949,36 & 5264,28 & 5783,97 & 5236,73 & 5501,24 & 5376,34 & 5323,37 & 5451,13 & 5437,53 & $82,74 \%$ \\
\hline Central Bohemia Region & 3,46 & 2,90 & 5,18 & 4,00 & 3,64 & 2,93 & 2,82 & 2,34 & 2,14 & 2,20 & $-50,59 \%$ \\
\hline South Bohemia Region & 3,69 & 3,90 & 3,72 & 1,55 & 1,61 & 1,60 & 1,21 & 0,79 & 0,95 & 0,86 & $-86,14 \%$ \\
\hline The Plzen Region & 3,80 & 1,86 & 1,62 & 2,32 & 2,81 & 2,52 & 2,39 & 2,37 & 1,94 & 1,94 & $-38,13 \%$ \\
\hline The Karlovy Vary Region & 0,04 & 0,04 & 0,04 & 0,05 & 0,06 & 0,04 & 0,04 & 0,04 & 0,03 & 0,03 & $-76,00 \%$ \\
\hline The Usti Region & 2,43 & 1,76 & 4,16 & 4,02 & 5,05 & 3,77 & 3,96 & 3,33 & 2,21 & 1,70 & $-48,02 \%$ \\
\hline The Liberec Region & 0,39 & 0,37 & 0,46 & 0,50 & 0,55 & 0,57 & 0,49 & 0,36 & 0,35 & 0,39 & $-38,73 \%$ \\
\hline $\begin{array}{l}\text { The Hradec Kralove } \\
\text { Region }\end{array}$ & 1,80 & 2,10 & 2,90 & 3,24 & 3,48 & 3,14 & 3,09 & 2,43 & 1,96 & 2,03 & $-22,13 \%$ \\
\hline The Pardubice Region & 3,70 & 3,03 & 4,29 & 4,91 & 5,16 & 5,08 & 4,43 & 2,83 & 2,49 & 2,27 & $-41,65 \%$ \\
\hline The Vysocina Region & 0,57 & 0,55 & 0,22 & 0,37 & 0,43 & 0,29 & 0,30 & 0,29 & 0,34 & 0,34 & $-19,71 \%$ \\
\hline $\begin{array}{l}\text { The South Moravian } \\
\text { Region }\end{array}$ & 57,61 & 64,46 & 73,77 & 89,66 & 104,88 & 109,13 & 134,95 & 152,73 & 189,53 & 241,01 & $177,93 \%$ \\
\hline The Olomouc Region & 1,18 & 1,54 & 1,09 & 1,93 & 1,74 & 1,21 & 1,45 & 1,32 & 1,41 & 1,33 & $-19,55 \%$ \\
\hline The Zlin Region & 0,67 & 0,83 & 0,78 & 0,90 & 1,00 & 0,82 & 0,87 & 1,18 & 0,95 & 0,75 & $-63,99 \%$ \\
\hline $\begin{array}{l}\text { The Moravian-Silesian } \\
\text { Region }\end{array}$ & 7,60 & 6,88 & 10,46 & 13,70 & 18,02 & 18,13 & 16,81 & 15,74 & 16,31 & 16,67 & $101,74 \%$ \\
\hline $\begin{array}{l}\text { Disparity against the } \\
\text { Capital City of Prague }\end{array}$ & 5570,84 & 5949,32 & 5264,25 & 5783,92 & 5236,67 & 5501,20 & 5376,30 & 5323,33 & 5451,11 & 5437,50 & $82,75 \%$ \\
\hline $\begin{array}{l}\text { Disparity between Capital } \\
\text { City of Prague and The } \\
\text { South Moravian Region }\end{array}$ & 5513,27 & 5884,9 & 5190,51 & 5694,31 & 5131,85 & 5392,11 & 5241,39 & 5170,64 & 5261,6 & 5196,52 & --- \\
\hline
\end{tabular}

Source: CZSO Regional Accounts Database, modified by authors 